\title{
The Rise of the Dunia Modern (Modern World) in Pramoedya Ananta Toer's Bumi Manusia (This Earth of Mankind)
}

\section{Ramon Guillermo}

\author{
University of the Philippines
}

\section{Abstract}

The first novel in Pramoedya Ananta Toer's (1925-2006) Buru Tetralogy, titled Bumi Manusia (This Earth of Mankind, 1980), is set in late nineteenth-century Indonesia and is mostly about the rise and emergence of the notions of the modern world (dunia modern) and of the nation (bangsa) and nationalism in the young hero Minke. This study proposes the use of Pramoedya's novel as a preliminary bounded corpus for exploring the semantic domains of the related terms dunia (world), bumi (earth) in Bahasa Indonesia. In the novel, the term dunia appears primarily in the phrase dunia modern (modern world), which is depicted as inseparable from its technology, science and capital. Bumi (earth) on the other hand, plays a crucial conceptual role in the novel, in the oft-repeated phrase Bumi Manusia (earth of mankind). The study will try to show how these two terms, dunia modern and bumi manusia, display a complex and often contradictory relationship in their use within the novel.

\section{Keywords}

Pramoedya Ananta Toer, globalization, novel, lexical analysis, conceptual history 
Pramoedya Ananta Toer (1925-2006) is one of Southeast Asia's most important novelists. His most well-known and well-studied work, the critically acclaimed Buru Tetralogy is set in the late nineteenth-century Indonesia and narrates the rise and emergence of the notions of the modern world and nationalism in the former Dutch colony. The story is told through the intellectual development and maturation of the young hero Minke. The Buru Tetralogy is made up of the four novels, Bumi Manusia (This Earth of Mankind, 1980), Anak Semua Bangsa (Child of All Nations, 1980), Jejak Langkah (Footsteps, 1985) and Rumah Kaca (House of Glass, 1988). Pramoedya originally told this story as a political prisoner to his fellow inmates on the island of Buru. It was eventually published after his release under house arrest, but due to suspicions of alleged "Marxist-Leninist" content, the novels were banned soon after in 1981 under the Suharto regime (Lane 363).

This study proposes the use of the first novel (Bumi Manusia or BM) in the tetralogy as a preliminary bounded corpus for exploring the semantic domains of the terms dunia (world), bumi (earth) in Bahasa Indonesia using frequency and collocation analysis. The word dunia is an Arabic loanword which is particularly well-known historically for its use in the phrase Dunia Melayu (Malay World), which pertains to an ideal of pan-“Malayan” cultural and racial unity (Salazar, 1998). Bumi, on the other hand, is a loanword from Sanskrit (Jones, 2007). The Trengganu inscription, dated 1303, contained the word bumi although the inscription itself is in Malay and written in the modified Arabic script, known as Jawi (Collins 16). Though these two words may have overlapping meanings and usages in contemporary Bahasa Indonesia, the general distinction which arises between these two terms is that bumi roughly corresponds to the notion of "earth" in the English language while dunia is more closely related to "world" (Echols, 2005). Nevertheless, they both have similar connotations to words in Bahasa Indonesia such as ardi (earth, ground, soil, land), bentala (earth, ground), buana (world, earth) and butala (earth, soil) (Endarmako, 2007). Bumi is related to bumiputra and pribumi which both mean "native." On the other hand, the adjective duniawi means "worldly," "secular," "transient" and "impermanent" (Echols, 2005). 
The discussion which follows does not deal with these individual words alone but with the more complex compound notions of Dunia Modern (modern world) and Bumi Manusia (earth of mankind).

\section{Dunia in the Indonesian Translation of the Communist Manifesto}

Before directly tackling the problem of the concepts of the dunia modern (modern world) and Bumi Manusia in BM, it might be instructive to look at some examples from the Indonesian translation of Marx and Engels' Manifest der kommunistischen Partei (Manifesto of the Communist Party, 1848). The particular translation which will be consulted here was first published in 1948 by the Committee on Translation of the Communist Party of Indonesia, which included its leader Dipa Nusantara Aidit as one of the translators (Marx and Engels 1970; Marx and Engels 1948). (Although this translation was based on the English translation, relevant terms from the German original will also be referred to here.) Some interesting aspects of the translation are collocations involving dunia and "modern." Weltmarkt (world market) appears in the original German four times and is translated consistently as pasar dunia. Weltliteratur (world literature) is translated as literatur dunia.

The word "modern" occurs seven times in the Manifesto and is translated into Indonesian with the following collocations, among others: revolusi modern (modern revolution), kelas buruh modern (modern working class), borjuis modern (modern bourgeoisie), kapitalis modern (modern capitalist), peradaban modern (modern civilization), industri modern (modern industry) and zaman modern (modern era).

The notion of the world associated with the translation of the Manifesto can be gleaned from the following phrases: menciptakan suatu dunia (create a world), menuju dunia baru (towards a new world), menguasai dunia (master the world; die Welt gewinnen), dunia yang terbaik (the best of worlds; die beste Welt), pembaharu-dunia (world improver, Weltverbesserer). ${ }^{1}$

1 Der menschliche Wesen (human being/essence) is somewhat puzzlingly translated as Dunia Kemanusiaan (the world of being human). 
Many of these usages are now quite common in modern Indonesian, and these collocational structures have probably shaped the contemporary usages and meanings of dunia and "modern." It should be remarked that although dunia modern (modern world) does not occur in the translation, the surrounding discursive context of dunia lends it a strong relationship to "modern."

The transformations wrought by the globalization of capital in the nineteenth century was described in some famously classic lines from the Communist Manifesto. It might be useful to compare these with the Indonesian translation and with a striking quote from the sequel of BM, Anak Semua Bangsa (Pramoedya 394):

\begin{tabular}{|c|c|c|}
\hline $\begin{array}{c}\text { Manifest der kommunistischen } \\
\text { Partei (1848) }\end{array}$ & $\begin{array}{c}\text { Manifesto Partai Komunis } \\
\text { (1948) }\end{array}$ & Anak Semua Bangsa (1980) \\
\hline $\begin{array}{l}\text { Die fortwährende Umwälzung } \\
\text { der Produktion, die ununter- } \\
\text { brochene Erschütterung aller } \\
\text { gesellschaftlichen Zustände, } \\
\text { die ewige Unsicherheit und } \\
\text { Bewegung zeichnet die Bour- } \\
\text { geoisepoche vor allen anderen } \\
\text { aus. Alle festen eingeroste- } \\
\text { ten Verhältnisse mit ihrem } \\
\text { Gefolge von altehrwürdigen } \\
\text { Vorstellungen und Anschau- } \\
\text { ungen werden aufgelöst, alle } \\
\text { neugebildeten veralten, ehe } \\
\text { sie verknöchern können. Alles } \\
\text { Ständische und Stehende } \\
\text { verdampft, alles Heilige wird } \\
\text { entweiht, und die Menschen } \\
\text { sind endlich gezwungen, ihre } \\
\text { Lebensstellung, ihre gegen- } \\
\text { seitigen Beziehungen mit } \\
\text { nüchternen Augen anzusehen. }\end{array}$ & $\begin{array}{l}\text { Senantiasa merevolusio- } \\
\text { nerkan produksi, kekacauan } \\
\text { tiada putus-putusnya dalam } \\
\text { segala syarat sosial, ketiadaan } \\
\text { kepastian serta kegelisahan } \\
\text { yang abadi itu membeda- } \\
\text { kan zaman borjuasi dengan } \\
\text { semua zaman yang terdahulu. } \\
\text { Segala hubungan yang telah } \\
\text { ditetapkan dan beku serta } \\
\text { berkarat, dengan rentetannya } \\
\text { berupa prasangka-prasangka } \\
\text { serta pendapat-pendapat } \\
\text { kuno yang disegani, disapu } \\
\text { bersih, segala yang dibentuk } \\
\text { baru menjadi usang sebelum } \\
\text { membatu. Segala yang padat } \\
\text { hilang larut dalam udara, } \\
\text { segala yang suci dinodai, } \\
\text { dan pada akhirnya manusia } \\
\text { terpaksa menghadapi dengan } \\
\text { hati yang tenang syarat-syarat } \\
\text { hidupnya yang sebenarnya, } \\
\text { dan hubungan-hubungannya } \\
\text { dengan sesamanya. }\end{array}$ & $\begin{array}{l}\text { Betul, yang dikatakan modal } \\
\text { lebih daripada hanya uang, } \\
\text { Tuan. Sesuatu yang mujarad, } \\
\text { abstrak, punya kekuasaan } \\
\text { gaib atas benda-benda nyata. } \\
\text { Semua yang menyebabkan } \\
\text { segala yang berpencaran } \\
\text { berkumpul, yang berkumpul } \\
\text { berpencaran, yang cair jadi } \\
\text { beku, yang beku dicairkan. } \\
\text { Segala berubah bentuk dalam } \\
\text { genggamannya. Yang basah } \\
\text { dia bikin kering yang kering } \\
\text { jadi basah. Dewa baru yang } \\
\text { mengepal seluruh dunia. Mem- } \\
\text { bosankan memang, tapi nyata. } \\
\text { Produksi, dagang, tetesan } \\
\text { keringat, angkutan, hubungan, } \\
\text { saluran-dan tak ada satu } \\
\text { orang pun dapat bebas dari } \\
\text { kekuasaan, pengaruh dan } \\
\text { perintahnya. Dan, Tuan Minke, } \\
\text { cara berpikir, cita-cita, diben- } \\
\text { arkan atau tidak, direstui atau } \\
\text { tidak olehnya juga. }\end{array}$ \\
\hline
\end{tabular}




\begin{tabular}{|c|c|c|}
\hline $\begin{array}{l}\text { Constant revolutionising of } \\
\text { production, uninterrupted } \\
\text { disturbance of all social condi- } \\
\text { tions, everlasting uncertainty } \\
\text { and agitation distinguish the } \\
\text { bourgeois epoch from all ear- } \\
\text { lier ones. All fixed, fast-frozen } \\
\text { relations, with their train of } \\
\text { ancient and venerable preju- } \\
\text { dices and opinions, are swept } \\
\text { away, all new-formed ones } \\
\text { become antiquated before } \\
\text { they can ossify. All that is sol- } \\
\text { id melts into air, all that is holy } \\
\text { is profaned, and man is at last } \\
\text { compelled to face with sober } \\
\text { senses his real conditions of } \\
\text { life, and his relations with his } \\
\text { kind. }\end{array}$ & $\begin{array}{l}\text { The constant revolutionizing } \\
\text { of production, continual dis- } \\
\text { order in all social conditions, } \\
\text { the lack of certainty with } \\
\text { its unending restlessness } \\
\text { differentiates the bourgeois } \\
\text { era with all eras of the past. All } \\
\text { fixed and congealed, rusted } \\
\text { relationships, with their series } \\
\text { of prejudices with respected } \\
\text { ancient opinions, are swept } \\
\text { away, everything that has just } \\
\text { taken form becomes worn out } \\
\text { before it can solidify. Every- } \\
\text { thing that is solid dissolves } \\
\text { into the air, everything that is } \\
\text { sacred is stained, and at last } \\
\text { one is forced to face with a } \\
\text { clear heart, the real conditions } \\
\text { of life, and each one's relation- } \\
\text { ships with others. }\end{array}$ & $\begin{array}{l}\text { Indeed, what is called capital is } \\
\text { more than just money, Tuan. It } \\
\text { is something abstract, having } \\
\text { a mysterious power on real } \\
\text { things. Everything that causes } \\
\text { all things scattered to gather } \\
\text { together, everything that is } \\
\text { gathered together to scatter, } \\
\text { what is liquid to become solid, } \\
\text { what is solid to melt. In its } \\
\text { hands, everything changes } \\
\text { shape. It dries what is wet, } \\
\text { and wets what is dry it. It is } \\
\text { a new god which holds in its } \\
\text { hands the whole world [dunia]. } \\
\text { Indeed this is boring, but real. } \\
\text { Production, trade, drops of } \\
\text { sweat, transportation, commu- } \\
\text { nication, channels - and there } \\
\text { is not a single person who } \\
\text { can be free from its power, } \\
\text { influence and commands. And, } \\
\text { Tuan Minke, ways of thinking, } \\
\text { dreams, correct or not, blessed } \\
\text { or not, are its own too. }\end{array}$ \\
\hline
\end{tabular}

The impact of capital is described in the Manifesto as ununterbrochene Erschütterung (continuous convulsions), ewige Unsicherheit (unending uncertainty) and Bewegung (movement). These are translated as kekacauan tiada putus-putusnya (disorder without end), ketiadaan kepastian (lack of certainty) and kegelisahan (disquiet). These characteristics, including the constant "revolutionization" of production are said to differentiate the bourgeois era from all other earlier ones. In short, these traits describe the zaman modern (modern era) with its industri modern (modern industry) and revolusi modern (modern revolution). It is an epoch in which, following Pramoedya's apparent paraphrase of Marx and Engels, "liquids become solid, solids melt and everything changes shape."

On the other hand, the prominent role of the notion of the "modern" in the novel Bumi Manusia can be seen just a few pages into the first chapter. There, Minke relates that of all modern inventions, he is most amazed by the reproduction of pictures by the thousands of copies on paper: 
Salah satu hasil ilmu-pengetahuan yang tak habis-habis kukagumi adalah percetakan terutama zincografi. Coba, orang sudah dapat memperbanyak potret berpuluh ribu lembar dalam sehari. Gambar pemandangan orang besar dan penting, mesin baru, gedung-gedung pencakar langit Amerika, semua dan dari seluruh dunia - kini dapat aku saksikan sendiri dari lembaran-lembaran kertas cetak. Sungguh merugi generasi sebelum aku - generasi yang sudah puas dengan banyaknya jejak-langkah sendiri di lorong-lorong kampungnya itu. Betapa aku berterimakasih pada semua dan setiap orang yang telah berjerih-payah untuk melahirkan keajaiban baru itu. Lima tahun yang lalu belum lagi ada gambar tercetak beredar dalam lingkungan hidupku. Memang ada cetakan cukilan kayu atau batu namun belum lagi dapat mewakili kenyataan sesungguhnya... Berita-berita dari Eropa dan Amerika banyak mewartakan penemuan-penemuan terbaru. Kehebatannya menandingi kesaktian para satria dan dewa nenek-moyangku dalam cerita wayang (Pramoedya 2-3).

[One of the results of science which I could not stop admiring is the printing press and above all, zincography. Imagine, one can already reproduce a portrait tens of thousands of times in a day. Pictures of great and important people, new machines, skyscrapers in America, everything and from the whole world-nowadays I can see these for myself on sheets of printed paper. Indeed the previous generation was greatly disadvantaged-it was a generation was contented with repeatedly stepping on its own tracks on the paths of their villages. How I thanked each and everyone who had exerted efforts in order to bring these new wonderful things to the world. Five years ago there were still no printed pictures circulating in my neighbourhood. True, there was printing from carved wood or stone but which could not yet faithfully represent reality... News from Europe and America report a lot about the latest inventions. These compete in greatness with the powers of knights and gods of my ancestors in the wayang stories.]

The progress of communication technologies (especially printing) has broken the self-contained, repeating circle of traditional communities. By means of the circulation of these pictures of faraway places, marvelous inventions and great personages, the experience of ordinary people is broadened beyond their villages. Interestingly, Minke's first attempt to define the word "modern" is simply the fact that a picture can be replicated up to tens of thousands of copies in a single day. 
Modern! Dengan cepatnya kata itu menggelumbang dan membiak diri seperti bakteria di Eropa sana. (Setidak-tidaknya menurut kata orang). Maka ijinkanlah aku ikut pula menggunakan kata ini sekalipun aku belum sepenuhnya dapat menyelami maknanya... Pendeknya dalam jaman modern ini potret sudah dapat diperbanyak sampai puluhan ribu sehari (Pramoedya 4).

[Modern! This word surged and flourished quickly like a bacteria in Europe. (At least people say so.) Allow me to use this word even if I do not understand completely its meaning. In short, in this modern age a picture can be replicated up to tens of thousands of times a day.]

This seemingly naïve definition relates quite strikingly to Walter Benjamin's discussion of how the "mechanical reproduction" of images leads to an epochal transformation in human consciousness and the undermining of the role of tradition in societies.

One might subsume the eliminated element in the term "aura" and go on to say: that which withers in the age of mechanical reproduction is the aura of the work of art. This is a symptomatic process whose signilcance points beyond the realm of art. One might generalize by saying: the technique of reproduction detaches the reproduced object from the domain of tradition. By making many reproductions it substitutes a plurality of copies for a unique existence. And in permitting the reproduction to meet the beholder or listener in his own particular situation, it reactivates the object reproduced. These two processes lead to a tremendous shattering of tradition which is the obverse of the contemporary crisis and renewal of mankind. ${ }^{2}$

2 "Man kann, was hier ausfällt, im Begriff der Aura zusammenfassen und sagen: was im Zeitalter der technischen Reproduzierbarkeit des Kunstwerks verkümmert, das ist seine Aura. Der Vorgang ist symptomatisch; seine Bedeutung weist über den Bereich der Kunst hinaus. Die Reproduktionstechnik, so ließe sich allgemein formulieren, löst das Reproduzierte aus dem Bereich der Tradition ab. Indem sie die Reproduktion vervielfältigt, setzt sie an die Stelle seines einmaligen Vorkommens sein massenweises. Und indem sie der Reproduktion erlaubt, dem Aufnehmenden in seiner jeweiligen Situation entgegenzukommen, aktualisiert sie das Reproduzierte. Diese beiden Prozesse führen zu einer gewaltigen Erschütterung des Tradierten einer Erschütterung der Tradition, die die Kehrseite der gegenwärtigen Krise und Erneuerung der Menschheit ist" $(1977,141)$. 
Benjamin states plainly in "Die Einzigkeit des Kunstwerks ist identisch mit seinem Eingebettetsein in den Zusammenhang der Tradition" that the uniqueness of a work of art is inseparable from its being imbedded in the fabric of tradition because an image and its interpretation are now not any longer embedded in its original context (143).

\section{Collocational Structures in BM: "Dunia" and "Bumi"}

In BM, the word "dunia" collocates twice with "modern" as "dunia modern" (modern world). Other important collocations are "ilmu dan pengetahuan modern" (modern science), "peradaban modern" (modern civilization), "jaman modern" (modern era). It was noted that these last two are also found in the Indonesian translation of the Communist Manifesto. "Weltliteratur" (world literature) is also found in BM as "sastra dunia" although "dunia cerita" (the world of literature/stories) also appears. Another phrase in BM which might have roots in Indonesian Marxist terminology is "pandangan dunia" (worldview).

Phrases such as "menjelajah dunia" (search the world), "menjelajahi dunia" (explore the world), "memiliki dunia“" (own the world), "memahami dunia" (grasp/comprehend the world), "dunia yang kehendaki" (the world which is desired) reveal as certain active orientation towards the world similar to that found in the Communist Manifesto.

The meaning of "dunia" as a limited "field of social activity" is found in the phrases: "dunia plesiran" (world of pleasure), "dunia kesenangan" (world of comfort), "dunia pelacuran" (world of prostitution), "dunia kedokteran" (medical world).

The "ketiadaan kepastian" (lack of certainty) used in the Indonesian translation of the phrase "ewige Unsicherheit" (eternal uncertainty) in the Communist Manifesto is echoed by the following phrases in BM: "betul aneh dunia ini" (true, this world is strange), "dunia terasa gelap" (the world felt dark), "dunia tanpa keamanan dan jaminan" (world without peace and certainty). One could surmise therefore that the rise of the notion of the "world" itself as expressed in the word "dunia" has become inseparable from modernity which lends to it strong connotations of modernity in BM. 
On the other hand, the use of "bumi" in BM reflects a deeper relationship to the natural world. This word is mentioned in such contexts as "gunung-gemunung dan langit dan bumi" (mountain range and sky and earth), "dari laut dan bumi" (from the sea and the earth." The new inventions which exploit "minyak bumi“ (petroleum) (appearing three time in BM) are also mentioned. Characteristic is also "seluruh permukaan bumi" (the whole face of the earth) which also appears in the Communist Manifesto as "seluruh muka bumi“ (the whole face of the earth; die ganze Erdkugel).

What fundamentally distinguishes "bumi" from "dunia" in BM are the following collocations: "bumi leluhur" (land of ancestors), "bumi kelahiran" (land of birth) and the related "bumi Belanda" (Holland's soil), "bumi Jawa" (Java's soil). These usages in BM imply a deeper relationship between "bumi“" and notions of "nature" and "tradition" rather than the "modern" connotations of "dunia."

However, it cannot be said that there exists a simple co-existence or division of labor between "dunia" and "bumi." The rise of the modern notion of the "world" threatens to transform and undermine traditional relationships in the "bumi leluhur" (land of ancestors).

\section{The "Bumi Manusia "and its Problems}

Minke observes that he has been deeply transformed by the Western education he has received in the Dutch language Hogere Burgerschool (HBS). The theme of alienation from origins is a recurring one in the novel, and Minke himself relates at the very beginning:

Ilmu dan pengetahuan yang kudapatkan dari sekolah dan kusaksikan sendiri pernyataannya dalam hidup telah membikin pribadiku menjadi agak berbeda dari sebangsaku pada umumnya. Menyalahi wujudku sebagai orang Jawa atau tidak aku pun tidak tahu. (2)

[The science and knowledge which I have received from school and witnessed myself expressed in life has already transformed my personality to become somewhat different from my countrymen in general. If this contradicts my being or not as a Javanese I do not know.] 
These changes in his thinking could no longer allow him to tolerate the blind submission to age and authority demanded by the Javanese tradition. Because of his unwillingness to submit to traditional authority, his mother calls him a "pembantah" (protester, rebel). Protesting against the customs which he felt humiliated him, he says:

Lecutkan cambukmu, raja, kau yang tak tahu bagaimana ilmu dan pengetahuan telah membuka babak baru di bumi manusia ini! (119)

[Crack your whip, rajah, you who do not know how science has already opened a new chapter in this earth of mankind!]

In his mind, science and modern knowledge had irreversibly opened a new chapter in the "bumi manusia." These new ideas have cast light on the earth ("menyuluhi bumi manusia"). And the world he inhabits is already something different from the colonial world which he was expected to serve as an educated native. He can no longer return to the traditional role which his family and community expected him to fulfill.

Kepriyayian bukan duniaku. Peduli apa iblis diangkat jadi mantri cacar atau diberhentikan tanpa hormat karena kecurangan? Duniaku bukan jabatan, pangkat, gaji dan kecurangan. Duniaku bumi manusia dengan persoalannya (120).

[The world of officialdom is not my world. Who gives a damn if the devil is promoted to give vaccines or to retire without honor because of corruption? My world is not that of position, rank, salary and corruption. My world is the earth of mankind with its problems.]

The certainty which tradition offered now seems deceptive and unsatisfactory to him, more especially so in the face of modernity. And he can no longer accept its solutions to the dilemmas and complications of life. His "world" (dunia) is no longer the world of position, rank and "tradition" but the "earth of mankind" (bumi manusia), full of problems, full of the "kekacauan" (confusion, disorder) and "ketiadaan kepastian" (lack of certainty). It can therefore be surmised that the notion of "Bumi Manusia" is actu- 
ally a response to and a product of the "Dunia modern." "Bumi Manusia" is emphatically no longer simply the "bumi leluhur" (land of one's ancestors), "bumi kelahiran" (land of birth) or "bumi Jawa" (land of Java). It differs in having attained a higher and more genuine universality. As opposed to the technical, scientific and economic connotations of "dunia modern," "bumi manusia" represents the rise of a notion of "humanity" which is capable of confronting it. Both concepts are driven towards universalism but in different directions.

At first, as opposed to tradition, science and the modern world initially seemed to offer Minke simple and definite answers to the problems of the "earth of mankind," but his youthful enthusiasm is eventually dampened by disillusionment.

Bumiku, bumi manusia ini kehilangan segala kepastiannya. Semua ilmu dan pengetahuan yang telah menjadi diriku sendiri meruap hilang (148).

[My world, this earth of mankind, lost all its certainty. All sciences and knowledge which have become my own have evaporated and disappeared.]

Minke here seems to have associated science and modern knowledge with the notion of certainty. However, these will eventually prove to be deceptive and incapable of providing balance and certainty in the "bumi manusia." Both tradition and modern science have therefore failed to give him the secure mooring in the world which he sought. This is once again emphasized in the following quote:

Ilmu pengetahuan semakin banyak melahirkan keajaiban. Dongengan leluhur sampai pada malu tersipu. Tak perlu lagi orang berapa bertahun untuk dapat bicara dengan seseorang di seberang lautan. Orang Jerman telah memasang kawat laut dari Inggris sampai India! Dan kawat semacam itu membiak bejuluran ke seluruh permukaan bumi. Seluruh dunia kini dapat mengawasi tingkah-laku seseorang. Dan orang dapat mengawasi tingkah-laku seluruh dunia... Tetapi manusia tetap yang dulu juga dengan persoalannya. Terutama dalam perkara cinta... Apa boleh buat dunia modern tak mampu mendirikan sekolah untuk jadi ahli dalam memenangkan cinta (316). 
[Science has increasingly produced wonders. To the point that the folk tales of our ancestors have been shamed. One needs no longer wait years to be able to speak with someone at the other side of the ocean. A German has already installed an ocean cable from England to India! Such cables have multiplied, stretching over the whole face of the earth (seluruh permukaan bumi). The whole world (seluruh dunia) can nowadays observe someone's behaviour. And one can observe the whole world's [seluruh dunia] behaviour... But humanity remains the same as before also in its problems. Above all in the matters of love... There is nothing that can be done, this modern world (dunia modern) cannot establish a school to become an expert at being successful in love.]

This passage seems to assert that the problems of humanity remain the same in essence throughout history, such that the solutions which science offers can be nothing but vain illusions. Such an "eternalization" of the problems of humanity ("manusia") would apparently contradict the thesis being advanced here about the novelty of Pramoedya's notion of "Bumi Manusia." However, instead of looking at it as referring to an eternal condition, the rise of the "Bumi Manusia" should probably be considered more accurately as an important symptom of the deepening and increasingly problematic character of human existence in the modern world. The "dunia modern" has transformed and surpassed the "bumi leluhur" (land of ancestors) but its sciences have nevertheless left untouched the question of what it means to be human and to strive being human. Its destruction of tradition as the basis of life has only made the problem of the meaning of human life even more urgent. The world may have changed massively in the late nineteenth century, as indeed Pramoedya depicts in the novel, but the questions faced by humanity encompassing such things as morality, justice and love have not changed fundamentally. On the contrary, these questions have only become more urgent. The "bumi manusia" therefore does not refer to some older conception of a natural and traditional world but it is world that has lost its moorings in ancient certainties just as much as the "dunia modern" itself. The feeling of homelessness (Heimatlosigkeit in German) in the world has intensified and, more than ever before, the existential problems of life come to the fore. 
Minke travels in one part of the novel, and not knowing what will happen on his journey, surrenders himself to the arbitrariness of life.

Pemandangan tambah lama tambah membosankan: tanah kersang, kadang kelabu, kadang kuning keputihan. Aku tertidur dengan perut lapar. Apa pun bakal terjadi, terjadilah. Uh, bumi manusia! (114)

[The landscape became more boring as time passed: barren land, sometimes gray, sometimes whitish yellow. I feel asleep with an empty stomach. What will happen, just happen. Uh, this earth of mankind]

\section{Conclusion}

Lest Pramoedya be accused of some kind of "naïve humanism," something which also undoubtedly can be read in some of his writings, Bertell Ollman's discussion of the so-called different "levels of generality" in Marx's writings might be of some use. According to Ollman, there are seven levels of generality in Marx, of which the following five are the most important: 1) The unique aspects of a person and situation; 2) The general aspects of people, their activities, and products as they exist and function within modern capitalism; 3) Capitalist mode of production; 4) Class society; 5) "Human society, the qualities people, their activities, and products have in common as part of the human condition. Here one is considering all human beings and the entire history of the species" (Ollman 89). Without attempting to make any rigid boundaries, one could assert that the notion of "dunia modern" in Pramoedya roughly corresponds to levels two and three dealing with "life under capitalism" and "capitalism" itself. On the other hand, "bumi manusia" roughly corresponds to level five which deals with the so-called "human condition.”

However, the constitution of the so-called "human condition" is arguably not just a simple given. According to Göran Therborn, the interpretation of the "human condition" in societies falls upon so-called "inclusive-existential ideologies." Therborn elaborates as follows, "[t]his type of ideological discourse provides meanings related to being a member of the world, i.e. the meaning of life, suffering, death, the cosmos, and the natural order. It 
concerns what life is, what is good and bad in life, what is possible in human existence, and whether there is a life after bodily death. The most common forms of discourse treating these questions are mythologies, religions, and secular moral discourse" (24). Furthermore, these "existential ideologies always exist in concrete historical forms, but are never reducible to them. These historically determined existential ideologies must then be subject to the same laws of reproduction and change as all other ideologies" (44).

The notion of the "Bumi Manusia" is therefore the existential conceptual twin of the notion "Dunia Modern." In the same way that the "world market" engendered the rise of a "world literature," the universalism of science (and of the colonialism which employed it to subjugate other nations) gives rise to the universalism of so-called "humanity." The "Bumi Manusia" is nothing other than an expression of the problem and riddle of being "human" in response to the "Dunia Modern." 


\section{Works Cited}

Benjamin, Walter. Das Kunstwerk im Zeitalter seiner technischen

Reproduzierbarkeit. In Illuminationen Ausgewählte Schriften 1, Walter Benjamin, 136-169. Frankfurt a. M.: Surhkamp, 1977.

Collins, James T. Bahasa Melayu bahasa dunia: Sejarah singkat. Yayasan Obor Indonesia, 1998.

Echols John M. Kamus Indonesia-Inggris. Gramedia Pustaka Utama, 2003.

Echols, John M. and Hasan Shadily. Kamus Inggris-Indonesia. Gramedia Pustaka Utama, 2005.

Eko Endarmoko. Tesaurus bahasa Indonesia. Gramedia Pustaka Utama, 2007.

Jones, Russell, ed. Loan-words in Indonesian and Malay. KITLV P, 2007.

- - -, ed. Loan-Words in Indonesian and Malay (Compiled by the Indonesian etymological project). http://sealang.net/indonesia/lwim/. Accessed 1 Nov. 2011.

Marx, Karl, and Friedrich Engels. Manifesto Partai Komunis, translated by D. N. Aidit, M. H. Lukman, A. Havili, P. Pardede and Nyoto, 1948.

- - -. Manifest der Kommunistischen Partei. Dietz Verlag, 1970.

Ollman Bertell. Dance of the Dialectic: Steps in Marx's Method. Uof Illinois P, 2003.

Pramoedya Ananta Toer. Anak semua bangsa: sebuah roman. Hasta Mitra, Jakarta, 1980.

- - -. Bumi manusia : sebuah roman. Hasta Mitra, 1980.

- - -. This Earth of Mankind, translated by Max Lane. Penguin Books, 1996.

Salazar, Zeus. "The Malay World: Bahasa Melayu in the Philippines." In The

Malayan Connection: Ang Pilipinas sa Dunia Melayu. Zeus A. Salazar, 81-107. Palimbagan ng Lahi, 1999.

Therborn, Göran. The Ideology of Power and the Power of Ideology. Verso, 1980. 